\title{
The Impact of Perceived Service Quality on Satisfaction: An Application on Marina Customers in Turkey
}

\author{
Görkem DİKEÇ ${ }^{1}$, Ali Cemal TÖZ² \\ ${ }^{1}$ Dokuz Eylul University, Institute of Social Sciences, Turkey \\ gorkem_dikec@hotmail.com, ORCID ID: orcid.org/0000-0003-3696-5536 \\ ${ }^{2}$ Dokuz Eylul University, Maritime Faculty, Turkey \\ ali.toz@deu.edu.tr, ORCID ID: orcid.org/0000-0001-5348-078X
}

\begin{abstract}
The main purpose of this study was to investigate the impact of perceived service quality on customer satisfaction in marinas in Turkey. A total of 134 customers from eight marinas which were included in the sample have participated to the research. The impact of services that customers receive on perceived service quality levels was analyzed.

This study mainly concludes that there is direct impact of quality of the services on customer satisfaction in marinas in Turkey. The results also show that the highest impact on customer satisfaction was "reliability and competence", followed by "management, planning and standards", and "physical assets, respectability and environment". Furthermore, the study shows that foreign and Turkish customers have significantly different opinions on some service quality variables. In the future a more comprehensive study could be done during high season. In addition, the survey could include additional languages at other marinas, which would increase the sample size. Future studies could compare marinas in other countries.
\end{abstract}

Keywords: Marina, Service Quality, Customer Satisfaction, Turkey.

\section{Alglanan Hizmet Kalitesinin Memnuniyete Etkisi: Türkiye'deki Marina Müșterileri Üzerine Bir Uygulama}

$\ddot{O} z$

Bu araștırmanın temel amacı Türkiye'de, marinalarda algılanan hizmet kalitesinin müșteri memnuniyeti üzerindeki etkisini araştırmaktır. Bu kapsamda örnekleme dâhil edilen sekiz marinadan toplam 134 müssteri araștırmaya katılmıștır. Bu müşterilerin almış oldukları hizmetlerin algıladıkları hizmet kalitesi düzeylerine etkisi analiz edilmiștir.

Bu çalışmada Türkiye'de marinalarda hizmet kalitesinin müşteri memnuniyetine doğrudan etkisi bulunduğu sonucuna ulaşılmıștır. Ayrıca araștırmanın sonuçları göstermektedir ki, müşteri memnuniyetindeki en büyük etkinin "güvenilirlik ve yetkinlik" değişkenleri olduğu, bu değişkenleri "yönetim, planlama ve standartlar" ve "fiziksel varlıklar, saygınlı ve çevre" değişkenlerinin izlediği sonucuna ulaşılmıştır. Bunun yanı sıra, bu çalışmada, yabancı ve Türk müssterilerin bazı hizmet kalitesi değişsenleri üzerinde yüksek anlamlllk düzeylerinde farkl görüşlere sahip oldukları görülmektedir. Gelecekte, bu çalışmanın yüksek sezonda, daha geniş bir ölçekte, farklı coğrafyaları ve farklı ulustan müşterileri de kapsayacakșekilde genişletilmesi önerilmektedir.

Anahtar Kelimeler: Marina, Hizmet Kalitesi, Müşteri Memnuniyeti, Türkiye. 


\section{Introduction}

Marine tourism is a continually growing sub-branch with an increasing contribution to tourism in general. The marine tourism industry consists of several business forms [1]. Yacht tourism, one of the largest components, is an activity that combines several natural and man-made aspects. In particular, it involves the active use of shores [2]. According to Arlı [3] an increase in the number of marinas and mooring capacities leads to competition and drives marina businesses to provide higherquality services. Despite the recent increase in the number of marinas, there are still fewer than in most countries in Europe. There are only 63 marinas in Turkey, which is a country that is surrounded by water on three sides and has a shoreline of $8337 \mathrm{~km}$ [4].

The ever-changing expectations of marina customers have been the most important determining factor in the increasingly competitive environment. Variability in marina customers' quality perceptions reveals the importance of determining service quality variables. Within this scope two specific objectives of this study can be defined. First one is to explore the service quality determinants in marinas. Second is to determine and analyze the differences in the perceptions of customers on service quality determinants in marinas and their impact on customer satisfaction. This explorative study will focus on the relationship between perceived service quality and customer satisfaction.

Previous studies [3,12, 13, 14] mostly focused on analyzing the only perceptions of customers on service quality determinants. In this study comparison of the perceptions and impact of service quality determinants on customer satisfaction are analyzed.

This paper uses the SERVQUAL service quality model developed by Parasuraman, Zeithaml and Berry [5]. Service quality is evaluated by the discrepancy between customer expectations and perceptions [6, 7]. Meeting the expectations of customers based on their needs and wants ensures that service is perceived as high quality [7].

A qualitative study was conducted based on the 22 expressions in the SERVQUAL survey form, which is adequately organized to reveal the dimensions of services provided at marinas. The interview form was used by experts in semi-structured interviews. Data were obtained from the qualitative study using the data collection tool that was developed to measure the effect of service quality and customer satisfaction variables. In parallel, a field study was conducted with the participation of yacht owners and captains who receive services from marinas. The data obtained were analyzed and a general evaluation was made. In the conclusion, the findings of qualitative and quantitative studies were compared.

\section{Literature Review}

In the current competitive environment between marinas, it is important to maintain existing customers and acquire new ones and hence service quality and perception are essential. This study evaluates service quality through customers' perception of services. Customer satisfaction plays a very important role in marketing and sustainability of activities.

Customers perceive the services they purchase in two ways: Satisfaction obtained during service and quality of service [8, 9]. Provision of customer satisfaction with quality service has an important place in marketing. Increasing service quality requires researching the needs and wants of yacht owners and captains as well as their perception of service quality. A review of current literature showed that perceived service quality and customer satisfaction are important on a daily basis. There are five dimensions of SERVQUAL methodology which measure the level of service quality [8]. 
Tangibility: As the name suggested that all the tangible things or physical facilities including personnel, equipment, building and renovation etc..

Reliability: It describes the capabilities to fulfill promised services accurately and dependably.

Responsiveness: It describes the intentions of the firm and its willingness towards customers' help.

Assurance: It involves the understandings and courtesy of employees, their capabilities to convey confidence and trust.

Empathy: It consists of caring and customized responsiveness to customers. This empathy contains communication, access and understanding the customer.

There are several studies $[3,10,11,12,13$, 14] on service quality based on information from marina managers and yacht owners and captains. Durukan [10] reported that the yacht mooring facilities in the Aegean region was customer oriented. Based on information from 35 yacht owners, he reported that yacht owners looked first at the reliability of marina authorities and employees, and secondly, the prices. They preferred marinas where they could berth their yachts. The least important factor when choosing a marina was the degree of name recognition in the yachting community. Akaltan and Nas [11] examined factors that affected customers' marina choices. Interviews were done with 35 yacht owners and captains. The top three factors that customers took into consideration were the location of the marina (preferring one that is located on north-south routes), availability of adequate and clean showers and toilets, and an active social life around the marina. Cosar and Nas [12] studied the criteria that affected marina preferences of yacht users. The most important factor stood out as security, followed by hygiene and cleanliness of shared areas (showers and toilets), social activities provided to the owners and captains of yachts, the living area, and other similar factors [12]. Sipahi, Onay, and Tanyeri [13] concluded that marinas that provided "good facilities" to yacht owners and captains, offered "new destination opportunities," and offered activities and services around the marina played an important role in marina preferences. The studies related to the marina service quality determinants are shown in Table 1.

Studies that measured service quality usually use SERVQUAL [14]. The study conducted by Sarl [14] concluded that "physical assets, reliability, eagerness, reliability, understanding the customer and

Table 1. Literature Related to the Service Quality Determinants in Marinas in Turkey

\begin{tabular}{|c|c|c|c|}
\hline METHOD & STUDY & AUTHOR(S) & YEAR \\
\hline SWOT Analysis & $\begin{array}{c}\text { Analyzing the quality of Aegean region marinas in the } \\
\text { perspective of customers }\end{array}$ & Durukan & 2004 \\
\hline Regression & $\begin{array}{l}\text { Marina operations and services management: An analytic } \\
\text { research on the relationship between service quality } \\
\text { perceptions of yachters and their satisfaction from marina } \\
\text { services, repurchase and recommend intentions }\end{array}$ & Sarı & 2011 \\
\hline Servqual & $\begin{array}{l}\text { The analysis of impact level of marinas' promotional } \\
\text { components in terms of demographical features }\end{array}$ & Arlı & 2012 \\
\hline $\begin{array}{l}\text { Semi structured } \\
\text { Interview }\end{array}$ & $\begin{array}{c}\text { Analyzing the marina selection factors: An application on } \\
\text { the marina located Cesme }\end{array}$ & Cosar and Nas & 2013 \\
\hline $\begin{array}{l}\text { Semi structured } \\
\text { Interview }\end{array}$ & $\begin{array}{l}\text { The marina selection criteria of yacht owners: An } \\
\text { application of IC Cesme marina }\end{array}$ & Akaltan and Nas & 2013 \\
\hline Regression & $\begin{array}{c}\text { Adaptation of hospitality service quality scales for marina } \\
\text { services }\end{array}$ & Sarı et al. & 2016 \\
\hline
\end{tabular}


communication" have a direct impact on customer satisfaction. In another study on the quality of service provided at marinas, Arl [3] used the SERVQUAL scale and identified service quality dimensions such as physical conditions, eagerness, amenability, trust, accessibility, boat services, security, empathy, and professionalism. Sarı et al. [15] conducted a study to explore adaptation processes of hospitality service quality scales for marina services. These factors have a significant impact on the general satisfaction of customers. The literature shows that there is no study performed to analyze impact of service quality determinants on customer satisfaction in marinas in Turkey. The main contribution of this study to the literature is the exploration of impact of perceived service quality on customer satisfaction in marinas in Turkey.

\section{Materials and Method}

\subsection{Sample and Data Collection}

The study was done in two stages, one qualitative and one quantitative. The goal of the qualitative study was to evaluate the quality of services offered at marinas. SERVQUAL questions were asked of eight medium and top-level managers at seven marinas in and around Izmir and Aydın. They were interviewed between 29 November and 30 December 2014. The final survey form was developed based on feedback during previous studies. Convenience sampling was employed, which is a non-random (judgmental) sampling method. The survey form was prepared both in English and Turkish and used with yacht owners and captains who received mooring services between 4 April and 17 May 2014 at the following marinas: Dirinler Levent Marina, IC Cesme Marina, Setur Altınyunus Marina, Port Alacati Marina, Teos Marina in the İzmir province; Setur Kusadasi Marina, D-Marin Didim Marina in the Aydın province; and Ece Saray Marina in the Mugla province. Field research collected a total of 146 survey forms; 12 were excluded due to erroneous or incomplete filling. The remaining 134 valid forms were included in the analysis; 31 were in English and 103 were in Turkish.

\subsection{Model of the Research}

The model of the study was adopted and modified from the empirical study by Dehghan [16] depicted in Figure 1. The figure shows the relationship between service quality and customer satisfaction and the determinants that defines each of them.

The model indicates that perceived service quality is considered as an initial determinant of customer satisfaction [17]. It shows that the quality of service measured by the SERVQUAL variables provide customer satisfaction. There are lots of specific techniques have been used in conceptual discussions and experimental practices of customer satisfaction, yet they seem to have at least one thing in common: They refer to the customer's relationship over time toward one specific object [18].

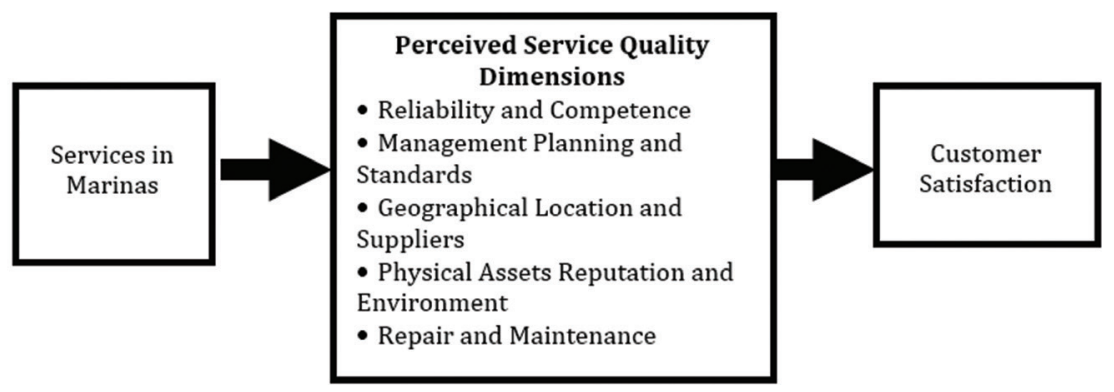

Figure 1. The Conceptual Model of Study

Source: Adopted from [16] 
The steps of the study are illustrated in Figure 2. According to the figure, initially literature review was conducted, and then quantitative method following qualitative technique was performed. Finally, analysis was carried out and findings were discussed.

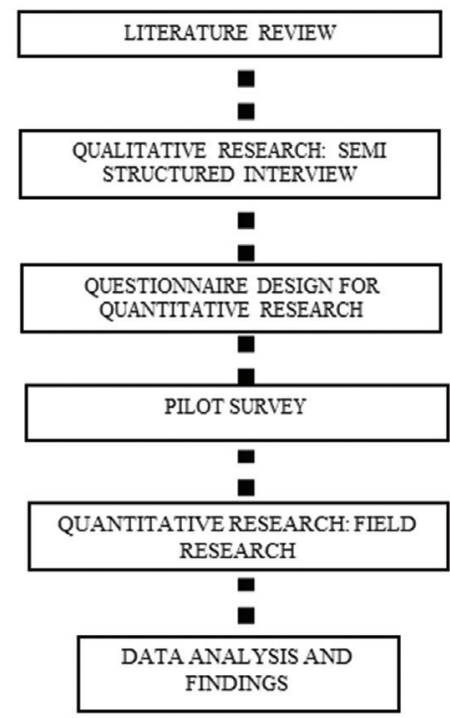

Figure 2. The Steps of Study

\subsection{Results}

In this study both qualitative and quantitative techniques were used to determine impact of perceived service quality on marina customers' satisfaction in Turkey. The results of those techniques are explained in detail below.

\subsubsection{Qualitative Research}

In this study initially a qualitative study has been conducted to determine the service quality determinants in marinas. The Semi-Structured Interview technique, which is the ability to gather opinions from experts from various area of expertise, has been selected to bring about consensus in this study [19]. This technique which is utilized to explore service quality determinants in marinas, contributed to create data collection tool for quantitative research process. The details of interview are shown in Table 2.

A face-to-face interview was conducted with the above-mentioned experts and new variables were added to the service quality variables obtained from the literature. Besides, permission has been obtained from the experts in the negotiations for the publication of the identity information. As a result of the interview, in the light of the feedback from the customers, it was seen that the new service quality variables in practice came to the forefront. The determinants of perceived service quality obtained from literature review and interview are shown in Table 3.

It is clear from the table that there are some service quality determinants considered as an important in addition to

Table 2. Details of Interviewees

\begin{tabular}{|c|c|c|c|c|}
\hline Expert & Company & Profession & Venue & Date \\
\hline Onur KUNDUZ & Port Alacati Marina & Marina Director & Office & 29.11 .14 \\
\hline Can AKALTAN & Cesme Marina & General Manager & Office & 01.12 .14 \\
\hline Hakan TELLIOĞLU & Setur Cesme Marina & Marina Director & Office & 01.12 .14 \\
\hline Bora ERGEZGİ & Dirinler Levent Marina & Marina Director & Office & 02.12 .14 \\
\hline Ylldız KAHRAMAN & Teos Marina & $\begin{array}{c}\text { General Manager } \\
\text { Asst. }\end{array}$ & Office & 13.12 .14 \\
\hline Zeynep ALTAN & Setur Kusadasi Marina & $\begin{array}{c}\text { Front Office } \\
\text { Manager }\end{array}$ & Office & 20.12 .14 \\
\hline Çağlar ALTUNTAȘ & Setur Kusadasi Marina & Marina Director & Office & 20.12 .14 \\
\hline Selçuk BALCI & D-Marin Didim Marina & Marina Director & Office & 30.12 .14 \\
\hline
\end{tabular}


Table 3. Main Sources of Determinants that Used in Questionnaire

\begin{tabular}{|c|c|c|c|c|c|}
\hline Determinants & $\begin{array}{c}\text { Literature } \\
\text { Review }\end{array}$ & Interview & Determinants & $\begin{array}{l}\text { Literature } \\
\text { Review }\end{array}$ & Interview \\
\hline Geographical position & $\sqrt{ }$ & $\sqrt{ }$ & Main infrastructures & $\sqrt{ }$ & $\sqrt{ }$ \\
\hline $\begin{array}{l}\text { Marine pollution } \\
\text { prevention procedures }\end{array}$ & $\sqrt{ }$ & $\sqrt{ }$ & Super structures & $\sqrt{ }$ & $\sqrt{ }$ \\
\hline Reliability & $\sqrt{ }$ & $\sqrt{ }$ & Common use areas & $\sqrt{ }$ & $\sqrt{ }$ \\
\hline $\begin{array}{l}\text { Risk assessment } \\
\text { procedures }\end{array}$ & $\sqrt{ }$ & $\sqrt{ }$ & Boat yard facilities & $\sqrt{ }$ & $\sqrt{ }$ \\
\hline $\begin{array}{l}\text { Crisis management } \\
\text { procedures }\end{array}$ & $\sqrt{ }$ & $\sqrt{ }$ & $\begin{array}{l}\text { Refueling and waste } \\
\text { disposing facilities }\end{array}$ & $\sqrt{ }$ & $\sqrt{ }$ \\
\hline $\begin{array}{l}\text { Quality management } \\
\text { applications }\end{array}$ & $\sqrt{ }$ & $\sqrt{ }$ & Repairing facilities & $\sqrt{ }$ & $\sqrt{ }$ \\
\hline $\begin{array}{l}\text { Operational } \\
\text { performance }\end{array}$ & $\sqrt{ }$ & $\sqrt{ }$ & Social activities & $\sqrt{ }$ & $\sqrt{ }$ \\
\hline $\begin{array}{l}\text { Managerial } \\
\text { performance }\end{array}$ & $\sqrt{ }$ & $\sqrt{ }$ & $\begin{array}{l}\text { Existence of yacht } \\
\text { equipment suppliers }\end{array}$ & $\sqrt{ }$ & $\sqrt{ }$ \\
\hline Security services & $\sqrt{ }$ & $\sqrt{ }$ & $\begin{array}{l}\text { Existence of spare part } \\
\text { suppliers }\end{array}$ & $\sqrt{ }$ & $\sqrt{ }$ \\
\hline Shelter infrastructure & $\sqrt{ }$ & $\sqrt{ }$ & $\begin{array}{l}\text { Presentability level } \\
\text { of staff }\end{array}$ & $\sqrt{ }$ & $\sqrt{ }$ \\
\hline Working hours & $\sqrt{ }$ & $\sqrt{ }$ & $\begin{array}{l}\text { Knowledge level of } \\
\text { staff }\end{array}$ & $\sqrt{ }$ & $\sqrt{ }$ \\
\hline $\begin{array}{l}\text { Cleanliness level of sea } \\
\text { water }\end{array}$ & & $\sqrt{ }$ & $\begin{array}{l}\text { Foreign language level } \\
\text { of staff }\end{array}$ & $\sqrt{ }$ & $\sqrt{ }$ \\
\hline $\begin{array}{l}\text { Pricing and charging } \\
\text { policy }\end{array}$ & & $\sqrt{ }$ & $\begin{array}{l}\text { Communication skill } \\
\text { level of staff }\end{array}$ & $\sqrt{ }$ & $\sqrt{ }$ \\
\hline $\begin{array}{l}\text { Group marina } \\
\text { membership }\end{array}$ & & $\sqrt{ }$ & Individual attention & $\sqrt{ }$ & $\sqrt{ }$ \\
\hline Car parking capacity & & $\sqrt{ }$ & $\begin{array}{l}\text { Quality and speed of } \\
\text { internet service }\end{array}$ & $\sqrt{ }$ & $\sqrt{ }$ \\
\hline Blue flag criteria & & $\sqrt{ }$ & $\begin{array}{l}\text { Feedback service } \\
\text { quality }\end{array}$ & $\sqrt{ }$ & $\sqrt{ }$ \\
\hline Golden anchor criteria & & $\sqrt{ }$ & Cheerful service & $\sqrt{ }$ & $\sqrt{ }$ \\
\hline Depth for berthing & & $\sqrt{ }$ & $\begin{array}{l}\text { Sportive and social } \\
\text { activities }\end{array}$ & & $\sqrt{ }$ \\
\hline $\begin{array}{l}\text { Reputation and } \\
\text { prestige }\end{array}$ & & $\sqrt{ }$ & Visual appeal & & $\sqrt{ }$ \\
\hline
\end{tabular}

literature review. Sea water quality, pricing policy, international quality indicators (blue flag, golden anchor), reputation, visual appeal, group marina membership, car parking capacity, social activities and berthing depth were also considered as service quality determinants by experts.

According to face to face interview results; suggestions and complaints received by the customers should be taken into consideration more quickly by marina management and the necessary improvements should be made on time. This result indicates that the reaction time is so slow.

Moreover, although the existence 
of the quality management system is important to the customer, it is seen that the implementation of this system is more important. At this stage, the customer wants to feel that an existing system is being implemented effectively.

\subsubsection{Quantitative Research}

The Cronbach Alfa value was used to evaluate the consistency of participants' answers. The reliability value of section B, which measures service quality in the data collection, was calculated as $0.966(96.6 \%)$. of the 134 marina customers who

Table 4. Profile of Respondents

\begin{tabular}{|c|c|c|c|c|c|c|c|}
\hline \multicolumn{2}{|c|}{ Variables } & \multirow{2}{*}{$\frac{\mathbf{N}}{119}$} & \multirow{2}{*}{$\frac{\%}{88.8}$} & \multicolumn{2}{|c|}{ Variables } & \multirow{2}{*}{$\frac{n}{68}$} & \multirow{2}{*}{$\frac{\%}{55.7}$} \\
\hline \multirow{3}{*}{ Sex } & Male & & & \multirow{3}{*}{ Type of Boat } & Sailing & & \\
\hline & Female & 15 & 11.2 & & Motor Yacht & 66 & 49.3 \\
\hline & Total & 134 & 100 & & Total & 134 & 100 \\
\hline \multirow{3}{*}{$\begin{array}{l}\text { Marital } \\
\text { Status }\end{array}$} & Married & 100 & 74.6 & \multirow{3}{*}{$\begin{array}{l}\text { Purpose of } \\
\text { Service }\end{array}$} & Private & 124 & 92.5 \\
\hline & Single & 34 & 25.4 & & Commercial & 10 & 7.5 \\
\hline & Total & 134 & 100 & & Total & 134 & 100 \\
\hline \multirow{5}{*}{ Age } & $19-25$ & 10 & 7.5 & \multirow{5}{*}{$\begin{array}{c}\text { Sea } \\
\text { Experience } \\
\text { (Years) }\end{array}$} & $<5$ & 27 & 20.1 \\
\hline & $26-35$ & 27 & 20.1 & & $6-10$ & 30 & 22.4 \\
\hline & $36-45$ & 27 & 20.1 & & $11-20$ & 41 & 30.6 \\
\hline & $>46$ & 70 & 52.2 & & $>21$ & 36 & 26.9 \\
\hline & Total & 134 & 100 & & Total & 134 & 100 \\
\hline \multirow{5}{*}{$\begin{array}{c}\text { Income } \\
\text { (Annual/\$) }\end{array}$} & $<10.000$ & 42 & 31.3 & \multirow{6}{*}{ Flag of Boat } & Turkish & 33 & 24.6 \\
\hline & $10.000-50.000$ & 61 & 45.5 & & United States & 66 & 49.3 \\
\hline & $50.000-100.000$ & 14 & 10.4 & & United Kingdom & 27 & 20.1 \\
\hline & $>100.000$ & 17 & 12.7 & & Germany & 5 & 3.7 \\
\hline & Total & 134 & 100 & & Other & 3 & 2.1 \\
\hline \multirow{3}{*}{ Nationality } & Turkish & 103 & 76.9 & & Total & 134 & 100 \\
\hline & Other & 31 & 23.1 & \multirow{5}{*}{$\begin{array}{l}\text { Assignments } \\
\text { on Board }\end{array}$} & Owner & 72 & 53.7 \\
\hline & Total & 134 & 100 & & Captain & 44 & 32.8 \\
\hline \multirow{10}{*}{$\begin{array}{l}\text { Professional } \\
\text { Status }\end{array}$} & Retired & 20 & 14.9 & & Owner/Captain & 11 & 8.2 \\
\hline & Sailor & 54 & 40.3 & & Other & 7 & 5.2 \\
\hline & Director & 21 & 15.7 & & Total & 134 & 100 \\
\hline & Self-employment & 9 & 6.7 & \multirow{7}{*}{$\begin{array}{c}\text { Education } \\
\text { Status }\end{array}$} & Primary School & 4 & 3.0 \\
\hline & Engineer & 10 & 7.5 & & Secondary School & 8 & 6.0 \\
\hline & Doctor & 8 & 6.0 & & High School & 42 & 31.3 \\
\hline & \multirow{2}{*}{ Other } & \multirow{2}{*}{12} & \multirow{2}{*}{9.0} & & Bachelor's Degree & 56 & 41.8 \\
\hline & & & & & MBA & 20 & 14.9 \\
\hline & \multirow{2}{*}{ Total } & \multirow{2}{*}{134} & \multirow{2}{*}{100} & & PHD & 4 & 3.0 \\
\hline & & & & & Total & 134 & 100 \\
\hline
\end{tabular}


participated, $88.8 \%$ (119) were male and $11.2 \%$ (15) were female. Of the boats included in the study, 55.7\% (68) were sailboats and $49.3 \%$ (66) were motorboats. Most of the boats had foreign flags, 49.3\% (USA), and $24.6 \%$ of the boats had Turkish flag. Of the Turkish boats, 23 were for used private purposes and 10 were for commercial purposes.

Table 4 shows that most of the respondents were university graduates (41.8\%, 56 people). Of the 134 participants, $76.9 \%$ (103) were Turkish nationals, and $23.1 \%$ (31) were foreign nationals; $40.3 \%$ (54) were sailors and $15.7 \%$ (21) were boat managers; $45.4 \%$ (61) earned US\$ 10,000-50,000 annually. Almost half of the respondents had 10 or more years' experience of working on a boat; $53.7 \%$ (72) were yacht owners, 32.8\% (44) were yacht captains, and $8.25 \%$ (11) were yacht owner-captains. Most boats were for private purposes $(92.5 \%, 124)$, which is a striking result. Most Turkish participants work sea-related professions whereas most foreign participants are retired. In European countries, with the economic value of yacht tourism, employment and types of income investment and operation stages is increasing. Nevertheless, the increase in the number of older and retired people in European countries as well as the importance given to navigational activities explains why most foreign respondents are retired. In addition, most customers who purchase service at marinas are yacht owners and captains; they do not need yacht captains. Table 5 shows the participants' nationality, and type of boat.

As for the distribution of boat types used by marina customers in the study, Turkish respondents mostly used motor yachts whereas foreign nationals preferred sailboats. It is thought that this difference is due to the fact that foreign customers, who have more time to spend more time at sea, prefer sailboats whereas Turkish customers who have shorter vacations choose boats that offer a more effective use of time.

During the low tourism season, most Turkish customers choose the IC Cesme marina while most foreign national customers choose Ece Saray Marina. Turkish customers prefer motor yachts and foreigners prefer sailboats.

In order to determine differences in perceptions of service quality, hypotheses were tested. The main hypotheses 1-3 evaluate differences in customers' perception of service quality.

$\mathbf{H}_{1}$ :Turkish and foreign yacht owners and captains evaluate marina service quality differently.

$\mathbf{H}_{2}$ :Yacht owners and captains of sailboats and motorboats evaluate marina service quality differently.

$\mathbf{H}_{3}$ :Yacht owners and captains of boats flying flag from different countries evaluate service quality of services offered at marinas differently from those who use motorboats.

To test hypotheses 1 , a total of 43 items were tested. Since 31 respondents

Table 5. Distribution of Customers Regarding to Marina and Boat Type

\begin{tabular}{|c|c|c|c|c|c|c|c|c|}
\hline Respondents & $\begin{array}{c}\text { IC } \\
\text { Ceșme }\end{array}$ & $\begin{array}{c}\text { Setur } \\
\text { Ceșme }\end{array}$ & $\begin{array}{c}\text { Port } \\
\text { Alacati }\end{array}$ & Levent & $\begin{array}{c}\text { Setur } \\
\text { Kusadasi }\end{array}$ & Teos & Ece Saray & $\begin{array}{c}\text { D-Marin } \\
\text { Didim }\end{array}$ \\
\hline Turkish & 27 & 11 & 11 & 5 & 12 & 18 & 10 & 9 \\
\hline Other & 7 & - & - & - & 6 & 2 & 16 & - \\
\hline Respondents & \multicolumn{3}{|c|}{ Sail Boat } & \multicolumn{5}{c|}{ Motor yacht } \\
\hline Turkish & \multicolumn{3}{|c|}{42} & \multicolumn{5}{c|}{5} \\
\hline Other & \multicolumn{3}{|c|}{26} & \multicolumn{5}{c}{} \\
\hline
\end{tabular}


are foreigners, 31 Turkish participants were chosen randomly from marinas that are dominated by foreign national respondents (Ece Saray Marina, IC Cesme Marina, Setur Kusadasi Marina, Teos Marina). The two groups were compared.

When the mean values of the accepted sub-hypothesis related to hypothesis 1 are examined, it can be seen that there is significant difference in the perceptions of foreign customers and Turkish customers for the $\mathbf{H}_{1.1}$ and $\mathbf{H}_{1.2}, \mathbf{H}_{1.4}, \mathbf{H}_{1.5}$, $\mathbf{H}_{16}$ sub-hypotheses.

According to the findings that foreign and Turkish customers have significantly different opinions on the adequacy of infrastructure, superstructure and common use areas of marinas, specifically services for the disabled, and services for boat repairing and overhauling. Although foreigners are not evenly distributed among marinas, reaching conclusions for four marinas is possible.

To test hypothesis 2, as shown in Table 6, when the mean values of sub- hypotheses with significant differences between yacht owners/yacht captains is examined, $\mathbf{H}_{2.1}, \mathbf{H}_{2.24}$ and $\mathbf{H}_{2.26}$ have higher mean values for sailboat users. The size of sailboats' accommodation is relatively smaller and uncomfortable than motor yachts. That's why sailboat users perceive service quality of physical facilities higher than motor yacht users.

To test hypothesis 3, since 33 participants had Turkish flags, 33 foreign flagged boats were chosen randomly from marinas where Turkish boats were more common (Ece Saray Marina, IC Cesme Marina, Setur Kusadasi Marina, Teos Marina, D-Marin Didim). The groups were compared in the same way as in hypothesis 1 . When the mean values of accepted sub-hypotheses are examined, it can be seen that the sub-hypotheses $\mathbf{H}_{3.11}, \mathbf{H}_{3.16}, \mathbf{H}_{3.26}, \mathbf{H}_{3.27}, \mathbf{H}_{3.28}, \mathbf{H}_{3.31}, \mathbf{H}_{3.32}$, $\mathbf{H}_{3.33}$ and $\mathbf{H}_{3.43}$ had higher mean values for Turkish flagged boats. Hence Turkish flagged boats report better service at these marinas.

Table 6. Results of Supported Hypotheses

\begin{tabular}{|c|c|c|c|c|}
\hline Sub Hypotheses & Mean $^{3}$ & $\mathbf{T}^{4}$ & $\begin{array}{l}\text { Two } \\
\text { Tails }^{5}\end{array}$ & Result \\
\hline \multicolumn{5}{|c|}{$\mathbf{H}_{\mathbf{1}}:$ Turkish and foreign yacht owners/yacht captains evaluate service quality of following services differently. } \\
\hline $\begin{array}{l}\mathbf{H}_{1.1}: \text { The infrastructure of the marina (transportation, } \\
\text { communication etc.) is modern and technological. }\end{array}$ & $\begin{array}{l}1: 3.1613 \\
2: 3.9032\end{array}$ & $\begin{array}{l}\mathrm{T}^{1}:-2.614 \\
\mathrm{~T}^{2}:-2.614\end{array}$ & $\begin{array}{l}.011 \\
.011\end{array}$ & Supported \\
\hline $\begin{array}{l}\mathbf{H}_{1,2}: \text { "The superstructure of the marina (mooring and harboring } \\
\text { facilities, shower-restroom etc.) is modern and technological" }\end{array}$ & $\begin{array}{l}1: 3.3548 \\
2: 3.9032\end{array}$ & $\begin{array}{l}\mathrm{T}^{1}:-2.031 \\
\mathrm{~T}^{2}:-2.031\end{array}$ & $\begin{array}{l}.047 \\
.047\end{array}$ & Supported \\
\hline $\begin{array}{l}\mathbf{H}_{1.4}: \text { Common use areas (shower \& restroom etc.) are sufficient } \\
\text { in number. }\end{array}$ & $\begin{array}{l}1: 3.6452 \\
2: 4.2903\end{array}$ & $\begin{array}{l}\mathrm{T}^{1}:-2.641 \\
\mathrm{~T}^{2}:-2.641\end{array}$ & $\begin{array}{l}.011 \\
.011\end{array}$ & Supported \\
\hline $\begin{array}{l}\mathbf{H}_{1.5}: \text { The infrastructure of the marina is convenient for the } \\
\text { disable yachters and visitors. }\end{array}$ & $\begin{array}{l}1: 2.7097 \\
2: 3.4839\end{array}$ & $\begin{array}{l}T^{1}:-3.151 \\
T^{2}:-3.151\end{array}$ & $\begin{array}{l}.003 \\
.003\end{array}$ & Supported \\
\hline $\mathbf{H}_{1.6}$ : Lifting and launching services in the marina is sufficient. & $\begin{array}{l}1: 3.3226 \\
2: 4.0323\end{array}$ & $\begin{array}{l}\mathrm{T}^{1}:-2.592 \\
\mathrm{~T}^{2}:-2.592\end{array}$ & $\begin{array}{l}.012 \\
.012\end{array}$ & Supported \\
\hline \multicolumn{5}{|c|}{${ }^{1}$ Turkish Yacht Owner/Yacht Captains ${ }^{2}$ Foreigner Yacht Owner/Yacht Captains } \\
\hline \multicolumn{5}{|c|}{$\begin{array}{l}\mathbf{H}_{2}: \text { Yacht owners/yacht captains who use sailboats evaluate service quality of following services offered at } \\
\text { marinas differently from those who use motor yachts. }\end{array}$} \\
\hline $\begin{array}{l}\mathbf{H}_{2.1}: \text { "The infrastructure of the marina (transportation, } \\
\text { communication etc.) is modern and technological." }\end{array}$ & $\begin{array}{l}1: 4.1324 \\
2: 3.6818\end{array}$ & $\begin{array}{l}\mathrm{T}^{1}: 2.429 \\
\mathrm{~T}^{2}: 2.419\end{array}$ & .016 & Supported \\
\hline $\mathbf{H}_{2.24}$ : "Marina staff is always cheerful, helpful and polite." & $\begin{array}{l}\text { 1: } 4.4118 \\
2: 4.0606\end{array}$ & $\begin{array}{l}T^{1}: 2.030 \\
T^{2}: 2.022\end{array}$ & .044 & Supported \\
\hline
\end{tabular}


Table 6. Results of Supported Hypotheses (cont')

\begin{tabular}{|c|c|c|c|c|}
\hline Sub Hypotheses & Mean $^{3}$ & $\mathbf{T}^{4}$ & $\begin{array}{l}\text { Two } \\
\text { Tails }\end{array}$ & Result \\
\hline $\begin{array}{l}\mathbf{H}_{2.26} \text { : "Marina staff fulfills the expected service in a timely } \\
\text { manner." }\end{array}$ & $\begin{array}{l}1: 4.3529 \\
2: 3.9394\end{array}$ & $\begin{array}{l}\mathrm{T}^{1}: 2.518 \\
\mathrm{~T}^{2}: 2.502\end{array}$ & .013 & Supported \\
\hline \multicolumn{5}{|c|}{${ }^{1}$ Sailing Boat ${ }^{2}$ Motor yacht } \\
\hline \multicolumn{5}{|c|}{$\begin{array}{l}\mathbf{H}_{3} \text { : Yacht owners/yacht captains who drive boats under different flags evaluate service quality of following } \\
\text { services offered at marinas differently from those who use motorboats. }\end{array}$} \\
\hline $\mathbf{H}_{3.11}$ : "Social activities at the marina are sufficient." & $\begin{array}{l}1: 3.5161 \\
2: 2.5161\end{array}$ & $\begin{array}{l}\mathrm{T}^{1}: 2.744 \\
\mathrm{~T}^{2}: 2.744\end{array}$ & $\begin{array}{l}.008 \\
.008\end{array}$ & Supported \\
\hline $\mathbf{H}_{3.16}$ : "Marina staff is well-groomed and presentable." & $\begin{array}{l}1: 4.6129 \\
2: 3.9355\end{array}$ & $\begin{array}{l}\mathrm{T}^{1}: 2.598 \\
\mathrm{~T}^{2}: 2.598\end{array}$ & $\begin{array}{l}.012 \\
.012\end{array}$ & Supported \\
\hline $\begin{array}{l}\mathbf{H}_{3.26} \text { : "Marina staff fulfills the expected service in a timely } \\
\text { manner." }\end{array}$ & $\begin{array}{l}1: 4.5484 \\
2: 3.7742\end{array}$ & $\begin{array}{l}\mathrm{T}^{1}: 3.181 \\
\mathrm{~T}^{2}: 3.181\end{array}$ & $\begin{array}{l}.002 \\
.002\end{array}$ & Supported \\
\hline $\mathbf{H}_{3.27}$ : "Marina staff fully fulfills the expected service." & $\begin{array}{l}1: 4.4839 \\
2: 3.8387\end{array}$ & $\begin{array}{l}\mathrm{T}^{1}: 2.631 \\
\mathrm{~T}^{2}: 2.631\end{array}$ & $\begin{array}{l}.011 \\
.011\end{array}$ & Supported \\
\hline $\begin{array}{l}\mathbf{H}_{3.28}: \text { "Enter and exit procedures of the boats are performed } \\
\text { timely at the marina." }\end{array}$ & $\begin{array}{l}1: 4.6452 \\
2: 4.1613\end{array}$ & $\begin{array}{l}\mathrm{T}^{1}: 2.354 \\
\mathrm{~T}^{2}: 2.354\end{array}$ & $\begin{array}{l}.022 \\
.023\end{array}$ & Supported \\
\hline $\mathbf{H}_{3.31}$ : "Security services provided at the marina are sufficient." & $\begin{array}{l}1: 4.2903 \\
2: 3.4194\end{array}$ & $\begin{array}{l}\mathrm{T}^{1}: 2.770 \\
\mathrm{~T}^{2}: 2.770\end{array}$ & $\begin{array}{l}.007 \\
.008\end{array}$ & Supported \\
\hline $\mathbf{H}_{3.32}$ : "Marina is protected against bad weather conditions." & $\begin{array}{l}1: 4.6452 \\
2: 4.0323\end{array}$ & $\begin{array}{l}\mathrm{T}^{1}: 2.953 \\
\mathrm{~T}^{2}: 2.953\end{array}$ & $\begin{array}{l}.004 \\
.005\end{array}$ & Supported \\
\hline $\mathbf{H}_{3.33}$ : "Marina staff is highly skilled." & $\begin{array}{l}1: 4.5484 \\
2: 3.8710\end{array}$ & $\begin{array}{l}\mathrm{T}^{1}: 2.888 \\
\mathrm{~T}^{2}: 2.888\end{array}$ & $\begin{array}{l}.005 \\
.006\end{array}$ & Supported \\
\hline $\mathbf{H}_{3.35}$ : "Marina staff pays attention individually to its customers." & $\begin{array}{l}1: 4.5161 \\
2: 3.7742\end{array}$ & $\begin{array}{c}\mathrm{T}^{1}: 3.103 \\
\mathrm{~T}^{2}: 3.103\end{array}$ & $\begin{array}{l}.003 \\
.003\end{array}$ & Supported \\
\hline $\mathbf{H}_{3.36}$ : "Communication skills of the marina staff are high." & $\begin{array}{l}1: 4.5161 \\
2: 3.9677\end{array}$ & $\begin{array}{l}\mathrm{T}^{1}: 2.447 \\
\mathrm{~T}^{2}: 2.447\end{array}$ & $\begin{array}{l}.017 \\
.017\end{array}$ & Supported \\
\hline $\begin{array}{l}\mathbf{H}_{3.43} \text { : "Sporting activities provided to the customers are } \\
\text { sufficient." }\end{array}$ & $\begin{array}{l}1: 3.2903 \\
2: 2.2903\end{array}$ & $\begin{array}{l}\mathrm{T}^{1}: 2.847 \\
\mathrm{~T}^{2}: 2.847\end{array}$ & $\begin{array}{l}.006 \\
.006\end{array}$ & Supported \\
\hline${ }^{1}$ Turkish ${ }^{2}$ Foreigner & & & & \\
\hline
\end{tabular}

${ }^{3}$ Mean values are based on 5 point Likert type scale. ${ }^{4}$ Test value, ${ }^{5}$ Significance level.

Hypothesis 4 and 5 evaluate perceived differences in service quality of people in different roles (owner or captain) and professions.

$\mathbf{H}_{4}$ : Customers in different roles (owner or captain) evaluate the quality of marina services differently.

$\mathbf{H}_{5}$ :Customers of different professions evaluate the quality of marina services differently.

To test hypothesis 4 , as shown in Table 7 there are significant differences for items $\mathbf{H}_{4.1}, \mathbf{H}_{4.6}$, and $\mathbf{H}_{4.43}$ between yacht owners and captains. According to the Tukey test, there are significant differences between yacht captains and owners in $\mathbf{H}_{4.1}(0.012)$, between captains and owners (0.024) in $\mathbf{H}_{4.6}$ and between yacht owner-captain and yacht owner (0.039) in $\mathbf{H}_{4.43}$.

To test hypothesis 5 , as shown in Table 7, sub-hypotheses $\mathbf{H}_{5.1}$ and $\mathbf{H}_{5.21}$ were accepted. In other words, there were significant differences between of yacht owners and captains with different professions. According to the post hoc Tukey test, there were significant differences for the "retired or other professions" group in $\mathbf{H}_{5.1}(0.026)$ and for the "self-employed or 
Table 7. Results of Supported Hypotheses

\begin{tabular}{|c|c|c|c|c|}
\hline Sub Hypotheses & Mean $^{3}$ & $\mathbf{T}^{4}$ & $\begin{array}{l}\text { Two } \\
\text { Tails }^{5}\end{array}$ & Result \\
\hline \multicolumn{5}{|c|}{$\begin{array}{l}\mathbf{H}_{4} \text { : Customers in different positions are evaluating the quality of following services offered at marinas } \\
\text { differently. }\end{array}$} \\
\hline $\begin{array}{l}\mathbf{H}_{4.1}: \text { "The infrastructure of the marina (transportation, } \\
\text { communication etc.) is modern and technological." }\end{array}$ & $\begin{array}{l}\text { Yacht Owner } \\
\text { Yacht Captain } \\
\text { Yacht Owner/ } \\
\text { Yacht Captain }\end{array}$ & $\begin{array}{l}4.1389 \\
3.5455 \\
3.8889\end{array}$ & 4.224 & Supported \\
\hline $\begin{array}{l}\mathbf{H}_{4.6} \text { : "Lifting and launching services in the marina are } \\
\text { sufficient." }\end{array}$ & $\begin{array}{l}\text { Yacht Owner } \\
\text { Yacht Captain } \\
\text { Yacht Owner/ } \\
\text { Yacht Captain }\end{array}$ & $\begin{array}{l}4.2361 \\
3.7045 \\
3.8889\end{array}$ & 3.662 & Supported \\
\hline $\begin{array}{l}\mathbf{H}_{4.43}: \text { "Sporting activities provided to the customers are } \\
\text { sufficient." }\end{array}$ & $\begin{array}{l}\text { Yacht Owner } \\
\text { Yacht Captain } \\
\text { Yacht Owner/ } \\
\text { Yacht Captain }\end{array}$ & $\begin{array}{l}3.1667 \\
2.8409 \\
2.2222\end{array}$ & 3.312 & Supported \\
\hline \multicolumn{5}{|c|}{$\begin{array}{l}\mathbf{H}_{5} \text { : Customers in different professional groups are evaluating the quality of following services offered at } \\
\text { marinas differently. }\end{array}$} \\
\hline $\begin{array}{l}\mathbf{H}_{5.1}: \text { "The infrastructure of the marina (transportation, } \\
\text { communication etc.) is modern and technological." }\end{array}$ & $\begin{array}{c}\text { Retired } \\
\text { Self Employed } \\
\text { Other }\end{array}$ & $\begin{array}{l}3.7000 \\
3.7500 \\
4.5000\end{array}$ & 6.068 & Supported \\
\hline $\begin{array}{l}\mathbf{H}_{5.21}: \text { "Parking capacity and conditions in the marina are } \\
\text { sufficient." }\end{array}$ & $\begin{array}{c}\text { Retired } \\
\text { Self Employed } \\
\text { Other }\end{array}$ & $\begin{array}{l}2.7000 \\
3.2024 \\
3.7667\end{array}$ & 3.629 & Supported \\
\hline
\end{tabular}

${ }^{3}$ Mean values are based on 5 point Likert type scale. ${ }^{4}$ Test value, ${ }^{5}$ Significance level.

other profession" group (0.003). $\operatorname{In} \mathbf{H}_{5.21}$, there was a significant difference for the "retired or other profession" group (0.025).

The factor analysis was conducted to classify items under the group of factors. Table 8 illustrates the results of a factor analysis, which identified five relevant groups:

1) Reliability and competence,

2) Management, planning, and standards,

3) Physical assets, reputation, and environment,

4) Location and suppliers,

5) Maintenance and repair.

The high KMO value of 0.903 shows that variables conform to the factor analysis. In addition, the Bartlett test was $0.1 \%$, which shows high significance $(p=0.000)$. A reliability analysis was done for each factor group (Table 6). The first group had the highest reliability, 0.953, whereas the fifth group had the lowest reliability, 0.659 . The relationship level among factors was calculated by Correlation analysis. The correlation matrices of factors are shown in Table 9.

Correlation analyzes are performed to determine the relationships between variables handled by the same scale type. In social sciences, there is a weak correlation between 0 and $(+,-) 0.19$, a medium correlation between $(+,-) 0,20$ and $(+,-) 0,39$ and 0,40 to $(+,-) 0.59$ is considered to be highly correlated (14). As understood from Table 9 that there is high correlation between Factor 1 and Factor $2 / 3$, and medium correlation among others.

Multiple regression analysis was used to evaluate the impact of perceived service quality on customer satisfaction. The dependent variable was the last item of the survey, overall satisfaction, which showed that $89.6 \%$ were generally satisfied. The model summary of regression analysis is illustrated in Table 10. 
Table 8. Factor Analysis Results for Service Quality Variables Perceived by Yacht Owners/Yacht Captains

\begin{tabular}{|c|c|c|c|}
\hline \multirow{2}{*}{\multicolumn{2}{|c|}{$\begin{array}{c}\text { Factors } \\
\text { Factor 1: Reliability and Competence } \\
\alpha: .953\end{array}$}} & \multicolumn{2}{|l|}{ Factors } \\
\hline & & \multirow{2}{*}{$\begin{array}{l}\text { Remuneration policy and tariff of the marina } \\
\text { are convenient. } \\
\text { Marina staff always takes into consideration } \\
\text { the customers' priorities and interests. }\end{array}$} & \multirow{2}{*}{.605} \\
\hline $\begin{array}{l}\text { Marina staff is always cheerful, helpful and } \\
\text { polite. }\end{array}$ & .770 & & \\
\hline Marina staff makes customers feel special. & .765 & $\begin{array}{l}\text { Marina engages in activities dealing with } \\
\text { marine pollution. }\end{array}$ & .498 \\
\hline $\begin{array}{l}\text { Marina staff fulfills the expected service in a } \\
\text { timely manner. }\end{array}$ & .763 & Internet service of the marina is efficient. & .448 \\
\hline $\begin{array}{c}\text { Marina staff pays attention individually to its } \\
\text { customers. }\end{array}$ & .744 & \multicolumn{2}{|l|}{$\begin{array}{c}\text { Factor 3: Physical Assets, Reputation and } \\
\text { Environment } \quad \alpha: .890\end{array}$} \\
\hline Marina staff is highly skilled. & .736 & $\begin{array}{l}\text { Common use areas (shower \& restroom etc.) } \\
\text { are clean. }\end{array}$ & .728 \\
\hline $\begin{array}{c}\text { Communication skills of the marina staff are } \\
\text { high. }\end{array}$ & .715 & $\begin{array}{l}\text { Physical conditions of marina accommodation } \\
\text { and facilities are adequate. }\end{array}$ & 675 \\
\hline $\begin{array}{l}\text { Enter and exit procedures of the boats are } \\
\text { performed timely at the marina. }\end{array}$ & .702 & $\begin{array}{l}\text { The superstructure of the marina (mooring } \\
\text { and harboring facilities, shower-restroom etc.) } \\
\text { is modern and technological. }\end{array}$ & .624 \\
\hline Marina staff fully fulfills the expected service. & .671 & The bunkering services are sufficient. & 607 \\
\hline Marina staff is eager in problem solving. & .669 & $\begin{array}{l}\text { Common use areas (shower \& restroom etc.) } \\
\text { are sufficient in number. }\end{array}$ & .592 \\
\hline Marina staff directs the customers correctly. & .652 & $\begin{array}{l}\text { The infrastructure of the marina is convenient } \\
\text { for the disable yachters and visitors. }\end{array}$ & .564 \\
\hline Marina staff is well-groomed and presentable. & .627 & $\begin{array}{c}\text { Cleaning and hygiene conditions in the marina } \\
\text { are sufficient. }\end{array}$ & .508 \\
\hline Language skills of the marina staff are satisfactory. & .593 & Waste collection services are sufficient. & .475 \\
\hline $\begin{array}{l}\text { Marina staff dedicates enough time to help in } \\
\text { all the customer needs. }\end{array}$ & .567 & $\begin{array}{l}\text { Customer feedback (opinions, complaints, } \\
\text { suggestions etc.) are considered important. }\end{array}$ & .469 \\
\hline $\begin{array}{l}\text { The services provided at the mooring and } \\
\text { harboring facilities are sufficient. }\end{array}$ & .556 & Sea water of the marina is clean. & .433 \\
\hline $\begin{array}{l}\text { The infrastructure of the marina } \\
\text { (transportation, communication etc.) is } \\
\text { modern and technological. }\end{array}$ & .555 & $\begin{array}{l}\text { The reputation of marina in the industry is } \\
\text { high. }\end{array}$ & .419 \\
\hline $\begin{array}{c}\text { Security services provided at the marina are } \\
\text { sufficient. }\end{array}$ & .531 & \multicolumn{2}{|l|}{$\begin{array}{l}\text { Factor 4: Geographical Location and Suppliers } \\
\qquad \alpha: .759\end{array}$} \\
\hline \multicolumn{2}{|l|}{$\begin{array}{l}\text { Factor 2: Management, Planning and Standards } \\
\qquad \alpha: .901\end{array}$} & $\begin{array}{l}\text { The location of the marina is close to the } \\
\text { strategical points (airport, hospital etc.) }\end{array}$ & .746 \\
\hline $\begin{array}{l}\text { Marina meets the requirements of } \\
\text { international standards (blue flag, anchor } \\
\text { regulation) adequately. }\end{array}$ & .732 & Supplying spare part is sufficient. & .671 \\
\hline $\begin{array}{l}\text { Sporting activities provided to the customers } \\
\text { are sufficient. }\end{array}$ & .709 & Supplying yachting equipment is sufficient. & .535 \\
\hline $\begin{array}{c}\text { Parking capacity and conditions in the marina } \\
\text { are sufficient. }\end{array}$ & .648 & $\begin{array}{l}\text { Marina is protected against bad weather } \\
\text { conditions. }\end{array}$ & .504 \\
\hline Social activities at the marina are sufficient. & .625 & \multicolumn{2}{|l|}{$\begin{array}{c}\text { Factor 5: Repair and Maintenance } \\
\alpha: .659\end{array}$} \\
\hline
\end{tabular}


Table 8. Factor Analysis Results for Service Quality Variables Perceived by Yacht Owners/Yacht Captains (cont')

\begin{tabular}{|c|c|c|c|}
\hline \multicolumn{2}{|c|}{ Factors } & \multicolumn{2}{c|}{ Factors } \\
\hline $\begin{array}{c}\text { Marina crisis management activities are } \\
\text { carried out in an effective manner. }\end{array}$ & .618 & $\begin{array}{c}\text { Lifting and launching services in the marina is } \\
\text { sufficient. }\end{array}$ & .700 \\
\hline $\begin{array}{c}\text { Marina risk management activities are carried } \\
\text { out in an effective manner. }\end{array}$ & .605 & $\begin{array}{c}\text { Repair and maintenance services of the marina } \\
\text { are sufficient. }\end{array}$ & .485 \\
\hline
\end{tabular}

Table 9. Correlation Matrices

\begin{tabular}{|l|c|c|c|c|c|}
\hline Factors & $\mathbf{1}$ & $\mathbf{2}$ & $\mathbf{3}$ & $\mathbf{4}$ & $\mathbf{5}$ \\
\hline Reliability and Competence & 1 &, $742^{* *}$ &, $758^{* *}$ &, $542^{* *}$ &, $530^{* *}$ \\
\hline Management, Planning and Standards &, $742^{* *}$ & 1 &, $717^{* *}$ &, $566^{* *}$ &, $551^{* *}$ \\
\hline Physical Assets, Reputation and Environment &, $758^{* *}$ &, $717^{* *}$ & 1 &, $567^{* *}$ &, $575^{* *}$ \\
\hline Geographical Location and Suppliers &, $542^{* *}$ &, $566^{* *}$ &, $567^{* *}$ & 1 &, $495^{* *}$ \\
\hline Repair and Maintenance &, $530^{* *}$ &, $551^{* *}$ &, $575^{* *}$ &, $495^{* *}$ & 1 \\
\hline
\end{tabular}

${ }^{* *} p<0,01$

Table 10. Regression Model Summary

\begin{tabular}{|c|c|c|c|c|c|}
\hline Model & $\mathbf{R}$ & $\mathbf{R 2}$ & Adjusted R2 & Estimated standard deviation & Sig \\
\hline 1 & .416 & .173 & .141 & .56924 & .000 \\
\hline
\end{tabular}

In regression analysis, the $\mathrm{F}$ value shows whether a test is statistically significant $(p<0.05) . R^{2}$ is a coefficient that shows the extent to which changes in the dependent variable are explained by independent variables. $\mathrm{R}^{2}$ was 0.173 , and $17 \%$ of "customer satisfaction from marinas", which is the dependent variable, is explained by service quality variables offered at marinas. Regression analysis results are shown in Table 11.

The $F$ value was 5.353 and the $p$ value was 0.000 , so the regression model was statistically significant. This means that estimating customer satisfaction with at least one of the independent variables is

Table 11. Multiple Regression Analysis Results

\begin{tabular}{|l|c|c|c|c|c|}
\hline & Beta & Std. Error & Std. Beta & t value & p value \\
\hline Independent Variables & .791 & .049 & & 16.086 & $.000^{* *}$ \\
\hline Reliability and Competence & .150 & .049 & .244 & 3.039 & $.003^{* *}$ \\
\hline $\begin{array}{l}\text { Management, Planning and } \\
\text { Standards }\end{array}$ & .144 & .049 & .235 & 2.919 & $.004^{* *}$ \\
\hline $\begin{array}{l}\text { Physical Assets, Reputation and } \\
\text { Environment }\end{array}$ & .125 & .049 & .204 & 2.532 & $.013^{*}$ \\
\hline $\begin{array}{l}\text { Geographical Location and } \\
\text { Suppliers }\end{array}$ & -.032 & .049 & -.052 & -.647 & .519 \\
\hline Repair and Maintenance & .073 & .049 & .119 & 1.475 & .143 \\
\hline F: 5.353 p: 0.000 & $\mathbf{R 2 : . 1 7 3}$ & & & & $\begin{array}{c}* * \mathbf{p}<\mathbf{0 . 0 1}, \\
\mathbf{F}_{\mathbf{p}<\mathbf{0 . 0 5}}\end{array}$ \\
\hline
\end{tabular}


statistically possible. The $\mathrm{p}$ values of the three of the five independent variables are less than 0.05 so they are all statistically significant. In other words, hypotheses $\mathbf{H}_{6}$, $\mathbf{H}_{\mathbf{7}}, \mathbf{H}_{\mathbf{8}}$ are supported but $\mathbf{H}_{\mathbf{9}}$ and $\mathbf{H}_{\mathbf{1 0}}$ are rejected.

The following survey items had a direct impact on overall satisfaction: Reliability and competence (B: .150; p<0.05), management, planning, and standards (B: .144 ; $\mathrm{p}<0.05$ ), physical assets, respectability, and environment ( $B$ : .125; $\mathrm{p}<0.05$ ). The highest impact on customer satisfaction was "reliability and competence" with B: .150 value, followed by "management, planning and standards" with B: .144, and "physical assets, respectability and environment" with B: 125 value. This means that these factors have a 15\%,14.4\% and $12.5 \%$ impact on customer satisfaction, respectively. The coefficient of the three variables shows that they have a direct positive impact on customer satisfaction.

\section{Conclusion and Discussion}

The main result of this study is that there is direct impact of perceived service quality on customer satisfaction in marinas in Turkey. The findings showed that there is positive statistical significance among the three dimensions of service quality (reliability and competence, management, planning, and standards, and physical assets, respectability and environment) and customer satisfaction. In order to increase service quality and ensure customer satisfaction, the most pressing items are "reliability and competence" variables, then those under "management, planning, and standards," and finally "physical assets, respectability, and environment." Hence "reliability and competence" variables should be given priority toward improving satisfaction and increasing repeat visits and recommendations.

This study concludes that environmental condition of marinas in Turkey perceived as low by all customers. Sea water quality is not at satisfactory level due to fact that there are lots of contaminators cause water pollution. The sea water quality has to be improved in marinas. It can be provided with some preventive measures such as increased disincentives and with promotive procedures.

Turkish customers are satisfied with the knowledge, skill, and punctuality of marina personnel and services, whereas non-Turkish customers significantly lower perceptions in this regard. This can be explained as foreigners' experience difficulties in terms of communicative skills. The problem both created by knowledge and level of speaking foreign language. Thus the marina administration must test the knowledge and communication skill level of its personnel both before and after recruitment. These findings imply that recruiting competent staff may be a critical aspect for foreign customers in judging the quality of marina services.

Foreigners have a more optimistic perception of the quality of service that they receive. It can be simply explained as they are probably happy with life in general. Because they are older, richer retired people on vacation.

Another significant conclusion of this paper is that captains of boats at marinas that are located far from city centers perceive sports and social activities as more important. Such activities must be found not only in high season but also during low season. Hence customers place importance on spending quality time at marinas.

The marinas in the study have more foreign customers, even in low season. Considering the location and climate of Turkey, it can be concluded that in Mediterranean Region yacht tourism season begins earlier than in other regions.

According to data, service quality is higher at the following marinas: Ece Saray Marina, IC Cesme Marina, Setur Kusadasi 
Marina, and Teos Marina. Hence foreign customers are more satisfied than Turkish customers. However, some variables are evaluated as low by both groups. These include internet services at marinas, sports activities, and social activities. For these services, which are common concerns of both Turkish and foreigner customers, improvements must be made and their sustainability must be ensured so that customer satisfaction can be kept at the highest level.

Foreign language levels of marina personnel are very important for dealing with foreign customers. In addition, infrastructure and superstructure suitable for handicapped yacht owners and captains or their guests and special equipment and systems are crucial for foreign customers. Services offered for disabled yachters at Ece Saray Marina, IC Cesme Marina, Setur Kusadasi Marina, Teos Marina were evaluated as high by foreign customers. The infrastructure components that were included are pedestals located in suitable intervals on piers, decks and floating docks that provide water and electricity, transportation, a communication network inside the marina, parking lot, and similar services. Modern and technological infrastructure components have an impact on the satisfaction of both Turkish and foreign yacht owners and captains.

In this study, a research model was conducted for marina businesses that are active in Turkey. There were some limitations of the study. Efforts were made to reach out to all active marinas in Turkey, but study did not include most of them all. The surveys were conducted during low season, which explains the low number of yacht owners and captains who were moored at marinas. In addition, the survey was only in English and Turkish, so those who did not speak these languages could not participate.

In the future a more comprehensive study could be conducted during high season. In addition, the survey could include additional languages at other marinas, which would increase the sample size. Future studies could compare marinas in other countries.

\section{Acknowledgments}

The authors would like to thank the management boards of marinas where field research was conducted for their support and assistance.

\section{Disclosure Statement}

No potential conflict of interest was reported by the authors.

\section{References}

[1] Orams, M. (1999). Marine tourism: development, impacts and management. London: Routledge.

[2] Akbayırl, K., Deveci, D. A., Balcl, G., Kurtuluş, E. (2016). Container Port Selection in Contestable Hinterlands. Journal of ETA Maritime Science, 2016; 4(3): 249-265.

[3] Arlı, E. (2012). Marina işletmeciliğginde tutundurma bileșenlerinden etkilenme düzeyinin demografik özellikler açısından incelenmesi Ticaret ve Turizm Eğitim Fakültesi Dergisi, 2012: (1): 25-52.

[4] Heron, R. and Juju, W. (2012). The marina: sustainable solutions for a profitable business. London: Routledge.

[5] Parasuraman, A., Zeithaml, V., Berry, L. (1985). A conceptual model of service quality and its implications for future research. Journal of Marketing, 1985: 49 (4): 41-50.

[6] Parasuraman, A., Zeithaml V. A., Berry, L. (1988). Servqual: a multipleitem scale for measuring consumer perceptions of service quality. Journal of Retailing, 1988: 64 (1): 12-37. 
[7] Donnelly, M., Wisniewski, M., Dalrymple, J., Curry, A. C. (1995). Measuring service quality in local government: the servqual approach. International Journal of Public Sector Management, 1995: 8 (7): 15-20.

[8] Zeithaml, V. A. and Bitner, M. J. (1996). Services marketing. New York: The Mc Graw-Hill.

[9] Kocbek, A. D. (2005). Yiyecek içecek sektöründe hizmet kalitesi ve müşteri memnuniyeti: etnik restoranlara yönelik bir araştırma, Yüksek Lisans Tezi, Anadolu Üniversitesi, Sosyal bilimler Enstitüsü, Eskişehir.

[10] Durukan, R.C. (2004).Egebölgesindeki yat bağlama tesislerinin müşteri yönlü değerlendirilmesi, Yüksek Lisans Tezi, Dokuz Eylül Üniversitesi Sosyal Bilimler Enstitüsü, İzmir.

[11] Akaltan, C. and Nas, S. (2013). Ziyaretçi yatçıların yat limanlarını tercih etme sebepleri: IC Çeşme marina uygulaması. Proceedings of 2 . Marine Tourism Conference, İzmir.

[12] Cosar, B. and Nas, S. (2014) Deniz turizminde yat limanı tercihini etkileyen faktörlerin tespiti: Çeşme bölgesi yat limanları üzerine bir çalıșma. Proceedings of 2. Marine Tourism Conference, İzmir.

[13] Sipahi, G., Onay, A., Tanyeri, M. (2015). Uluslararası pazarlarda Türk marinalarının marka konumlandırma stratejileri: Çeșme ve Didim marina örnekleri. Dokuz Eylül Üniversitesi Denizcilik Fakültesi Dergisi, 2015:7(1):113-145.

[14] Sarl, F. Ö. (2011). Marina işletmelerinde hizmet yönetimi: yatçıların hizmet kalitesi algılamaları ile marinadan tatminleri, tekrar tercih ve tavsiye etme eğilimleri arasındaki ilişkinin analitik incelenmesi, Doktora Tezi, Dokuz Eylül Üniversitesi, Sosyal Bilimler Enstitüsü, İzmir.
[15] Sari, F. O., Bulut, C., Pirnar, I. (2016). Adaptation of hospitality service quality scales for marina services. International Journal of Hospitality Management, 54: 95-103.

[16] Dehghan A. 2006. Relationship between service quality and customer satisfaction: In the case of CCG (Customer Centric Group) CO.

[17] Boohene. R. and Agyapong G. K. Q. (2011). Analysis of the antecedents of customer loyalty of telecommunication industry in Ghana: the case of Vodafone. International Business Research, 2011: 4 (1): 229240.

[18] Soderlund, M. (1998). Customer satisfaction and its consequences on customer behavior revisited. International Journal of Service Industries Management, 1998: 9(2): 169-88.

[19] Stewart, D. J. and Cash, W.B. (1985). Interviewing principles and practices. New York: Mc Graw Hill. 